\title{
The birth of an African journal: PHCFM
}

Author:

Gboyega A. Ogunbanjo 1

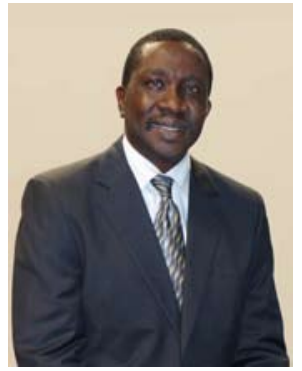

Affiliation:

${ }^{1}$ Department of Family

Medicine, University of

Limpopo, South Africa

Correspondence to:

Gboyega A. Ogunbanjo

e-mail:

gao@intekom.co.za

\section{Postal address:}

Department of Family

Medicine \& Primary

Health Care, Box 222,

Medunsa 0204, South

Africa

\section{Keywords:}

primary health care;

family medicine;

African research; online

publishing; OpenJournals

Publishing

\section{Dates:}

Received: 25 Sept. 2009

Accepted: 28 Sept. 2009

Published: 03 Oct. 2009

How to cite this article: Ogunbanjo GA. The birth of an African Journal: PHCFM. Afr J Prm Health Care Fam Med. 2009;1(1), Art. \#133, 1 page. DOI: 10.4102/phcfm.v1i1.133

Note:

This is the first editorial of the African Journal of Primary Health Care \& Family Medicine (PHCFM).

(C) 2009. The Authors. Licensee: OpenJournals Publishing. This work is licensed under the Creative Commons Attribution License.
A few years ago, when the idea was muted to have a journal that would provide the platform for primary care physicians and practitioners to publish their research work, it was in recognition of the vacuum that existed on the continent for such a journal. The official launch of this exciting new journal took place on 17-21 November 2008, at the Primafamed 'Improving the quality of family medicine training in SubSaharan Africa' conference (www.primafamed.ugent.be), in Kampala, Uganda.

The journal is co-financed by the Flemish Interuniversity Council (VLIR), Department for University Cooperation for Development, through the project VLIR-ZEIN 2006 PR320, with financial support from the Belgian government, Directorate General for Development Cooperation (www.vliruos.be). It also received sponsorship from the Interuniversity Center for GP-education (www.icho.be); the Global Health through Education Training and Service (www.ghets.org); The Network Towards Unity for Health (www. the-networktufh.org); European Forum for Primary Care (www.euprimarycare.org); and EDULINK (www.acp-edulink.eu), a programme funded by the European Union and implemented by the African, Caribbean and Pacific Group of states (ACP) Secretariat to improve the effectiveness and the impact of ACP-EU co-operation in the field of higher education.

Since its inception as an online journal in January 2009, the website has been inundated with submissions of good quality original articles, reviews and case studies from the African continent. The pool of excellent reviewers has contributed tremendously to the quality of the published articles. The peer-review process for each article is anonymously done from the moment it is submitted online until publication. Obviously with varying bandwidth and other energy-related issues associated with Internet connectivity within the African continent, there have been teething problems with the online submission process and followup of the peer-review process by authors. We have been able to overcome this with a back-up system using e-mails to communicate with authors when they struggle to access and monitor progress of their articles.

It is heartening to note that within the nine month period after the journal came online, it received over 120 articles covering the length and breadth of primary health care and family medicine. Obviously some were not within the scope of the journal, but for the 30 articles already published as at the time of this editorial, they were diligently peer-reviewed, proofread and edited. I am happy to inform you that the journal is already indexed with the African Index Medicus (AIM), which is a database sponsored and supported by the World Health Organization, in collaboration with the Association for Health Information and Libraries in Africa (AHILA). They have produced this international index to African health literature and information sources as a repository for articles published in or related to Africa to encourage local publishing. Printed knowledge generated in African countries is given global exposure in the African Index Medicus and it is hoped that this will promote African publishing by encouraging researchers to publish in their country or regional journals, while still having the opportunity to compete for publication space in the few world-wide 'prestigious' journals. ${ }^{1}$ Application has been submitted for the journal's accreditation with the South African Post Secondary Education (SAPSE) database. The most recent exciting news was when Wonca endorsed the journal and launched it via the Wonca Global Family Doctor homepage http:/ /www.globalfamilydoctor.com/links/link/onlinejournals.asp?refurl=ed

Obviously it is early days for this new publication, but the editorial team and I are very optimistic that it will grow from strength to strength. This is a special appeal to all colleagues on the African continent and beyond that this is our journal and your continued support through submission of good quality, relevant articles will make this journal a force to be reckoned with in the foreseeable future. A special thanks to Professor Pierre de Villiers of OpenJournals Publishing (AOSIS) for your faith in me when you interviewed me to consider taking up the challenge of starting this new journal as its first Editor-in-Chief in August 2008. This editorial would be incomplete without saying a special word of thanks to Rochelle Bronkhorst, Title Operations Coordinator of PHCFM and the rest of the OpenJournals Publishing team who keep me on my toes with progress reports on the peer-reviews of submitted articles.

As you read through this volume of the first African Journal of Primary Health Care \& Family Medicine, give it a thought to publish a considerable proportion of your future research work in this exciting journal. We are indebted to our sponsors for their contribution to the journal for the betterment of African health and human capacity development of its researchers. I end this editorial with this quote by Albert Schweitzer (1875-1965) on the meaning of life: 'Only a life lived for others is a life worthwhile'.'

\section{Gboyega A. Ogunbanjo}

Editor-in-Chief

\section{REFERENCES}

1. World Health Organization - Regional Office for Africa. African Index Medicus [homepage on the Internet]. No date [cited 24 Sept. 2009]. Available from: http://indexmedicus.afro.who.int/

2. Lewis JJ. Life Quotes [homepage on the Internet]. 2003 [cited 24 Sept 2009]. Available from: http:// www.wisdomquotes.com/cat_life.html. 